\title{
GENOMICS, PUBLIC HEALTH AND IDENTITY
}

\section{Ruth Chadwick*}

\begin{abstract}
This paper questions the utility of the ethical principles that are usually invoked to deal with genomic issues, particularly genetic databases. Concepts such as solidarity, benefit sharing, equity, public participation, and collective identity are discussed. The author argues that genetic banks are precipitating new concern over group interest, as opposed to concern over issues arising from individualistic medical ethics. Genomics era needs new paradigms in ethics. An individualistic approach based on choice and autonomy is not useful, because we make choices not only as individuals but also as members of different groups. The doctrine of informed consent evolved in different historical conditions from the ones we face in the era of genomics. This is complicated by the global context of genetic research, in addition to powerful commercial interests. This suggests that it is not sufficient to move from an individual-centred ethic approach to a more community-centred one; an approach of renegotiating the relationship between individual and community. We need also to be clear about what the interests at stake are, which may mean reconceiving the terms 'individual' and 'community' in this context and the ways in which their interests are affected, identifying the sources of collective identity that are at stake.
\end{abstract}

Keywords: Genomics, ethics, biobanks, collective identity, individual interests, collective interests, community

\section{GENÓMICA, SALUD PÚBLICA E IDENTIDAD}

Resumen: Este artículo cuestiona la utilidad de los principios éticos que son generalmente aludidos para abordar problemas de genómica, particularmente los de bancos de datos genéticos. Conceptos como solidaridad, compartir los beneficios, equidad, participación pública e identidad colectiva son discutidos. La autora sugiere que los bancos de datos genéticos están generando nuevas preocupaciones sobre los intereses del grupo, preocupaciones opuestas a los temas de una ética médica individualista. La era de la genómica necesita nuevos paradigmas éticos. Un enfoque individualista basado en la elección y la autonomía no es útil, puesto que tomamos decisiones no sólo como individuos sino también como miembros de diferentes grupos. La doctrina del consentimiento informado surgió en condiciones históricas diferentes de las que enfrentamos en la era de la genómica. Esto se complica por el contexto global de la investigación genómica y la presencia de poderosos intereses comerciales. Ello sugiere que no es suficiente moverse desde un enfoque centrado en el individuo a un enfoque más centrado en la comunidad; uno de renegociación de la relación entre individuo y comunidad. Necesitamos también tener claro cuáles son los intereses en riesgo, lo que puede significar redefinir los términos “individuo” y “comunidad” en este contexto y los modos en que sus intereses pueden ser afectados, identificando las fuentes de identidad colectiva que están en riesgo.

Palabras clave: Genómica, ética, bancos de datos genéticos, identidad colectiva, intereses individuales, intereses colectivos, comunidad

\section{GENOMICA, SAUDE PÚBLICA E IDENTIDADE}

Resumo: Esse artigo questíona a utilidade dos princípios éticos que se aludem geralmente para abordar problemas do genoma, em particular os de bases de dados genéticas. Conceitos tão a solidariedade, a dividir os benefícios, a equidade, a participação pública, e a identidade coletiva pública tratam. $\mathrm{O}$ autora sugire que as bases de dados genéticas estão gerando novas inquietudes pelos juros do grupo, inquietudes opostas aos temas de uma ética médica individualista. A era da genômica necessita de novos paradigmas éticos. Um enfoque individualista baseado na a eleição e a autonomia não é útil, porque nós tomamos decisões não apenas como indivíduos como também como membros de diferentes grupos. A doutrina do consentimento fundamentado surgiu em diferentes condições históricas das quais nós olhamos na era da genômica. Isto se complica mais pelo contexto global da pesquisa genômica e da presença de juros comerciais potentes. Isto indica que não é suficiente de mover de um enfoque estado centrado no indivíduo a um enfoque mais centrado na comunidade; um de renegociação da relação entre individuo e a comunidade. Nós necessitamos estar também seguros o qual são os juros em risco, que pode significar redefinindo os terminos do "indivíduo" e a "comunidade” nesse contexto e as modalidades nestes seus juros podem ser afetados, identificando as fontes de identidade coletiva que estão em risco.

Palavras chave: Genômica, ética, bases de dados genéticas, identidade coletiva, juros individuais, juros do coletivo, comunidade

ESRC. Centre for Economic and Social Aspects of Genomics (CESAGen). Lancaster University, UK.

Correspondence: r.chadwick@lancaster.ac.uk 


\section{Introduction}

The growth of a public health agenda in genomics has raised anew the debate about genetic exceptionalism. In the field of ethics, while in clinical genetics individualism has prevailed, proposals for population biobanks have invoked principles of solidarity and benefitsharing; concepts of gift and global public goods. What is needed, however, is attention to notions of identity in both contexts, individual and collective.

Science (6 June 2003) carried a story about a proposal to establish an African-American population biobank. The aim is to collect DNA samples from 25,000 volunteers over five years to "help disentangle genetics from socio-economic and other environmental factors in understanding disease among African Americans". It is also hoped that it will change attitudes among this group, who has been distrustful of medical research since the scandal of the Tuskegee syphilis studies. As the Science article points out, the role of race and ethnicity in thinking about medical ethics and policy is controversial because the genetic differences between individuals within a 'race' are greater than differences between ethnic groups. This reinforces the view that differential incidence of diseases between groups may be strongly influenced by socio-economic factors such as discrimination. Nevertheless such biobanks will, it is envisaged, facilitate the acquisition of more soundly based information on the respective inputs of genes and environment.

While health inequalities between different groups have long been an issue in medical ethics, I want to suggest that the move to population biobanks puts group interests, rather than individualistic medical ethics, more prominently on the agenda. The question is whether we have the theoretical resources to deal with this. Ironically, as we move in this direction, the purported benefits of genetic research are increasingly framed in terms of individual benefits, as in the clams for the future of individualised prescribing arising out of pharmacogenetics and nutrigenomics. The following quotation is illustrative of an approach which sees genetic possibilities as a mechanism of individual empowerment:

While rapid progress continues, there is much you can do now for yourself and your loved ones. Know your family history, be cognizant of your ethnic origin, determine your genetic susceptibilities, opt for necessary gene tests, take preventive actions, establish appropriate surveillance, and seek pre-emptive treatment where applicable. In this way, you can exercise control over your genetic destiny, secure your health, and -in more ways than you yet realize- save your life (Milunsky, 2001, xv).

I want to suggest that we need to think again about individualism: in particular, reliance on the individual choice model alone is likely to prove insufficient. And yet social science research, in the UK at least, has suggested that people are becoming increasingly individualistic in their thinking ${ }^{1}$.

The more that we understand about the human genome, the greater the possibilities for developing tests, of different kinds, that can be offered to individuals. Discussion initially focused on cases such as establishing that an individual has a disorder traceable to a single gene, such as Huntington's. If an individual tests positive for the Huntington's gene he or she is virtually certain to develop the disorder in middle life.

\footnotetext{
Research by Paul Whiteley for the ESRC Democracy and Participation programme, reported on BBC Radio 4 Today programme 24 September 2003
} 
Not all genetic tests are of this kind however. Others would enable two would-be parents to establish whether they were both carriers of a recessive gene that would give them a one-infour chance of having an affected child. Again, there are tests that establish, not whether an individual has one of the genetic disorders as such, but whether he or she has a genetic make-up that would put him or her at higher than average risk of developing one of the common diseases, such as breast cancer, or heart disease.

Into this frame we now have to put the development of new types of test. We are all familiar with going to the doctor and receiving a prescription for medication. It is envisaged that, in the light of advances in genetics, the practice of medicine as we know it may in future be quite different. Among the types of genetic test that are likely to become available in the next few years is a 'medicine response test'. The point of this will be to test individuals for information regarding their likely response to drugs in the light of their particular genetic profile. Pharmacogenetics is the term used to describe the use of genetic information to show how variations in patients' DNA may affect drug responsiveness and susceptibility to side effects. Pharmacogenetics will enable us to identify who will be likely to benefit and who harmed. If we could establish this in advance, the argument goes, doctors could prescribe more safely and effectively - prescribing would become more tailored to the individual than it is now. The whole practice of medicine could become much more 'geneticised' by this development in what is called pharmacogenetics. It is not clear, however, how this would work would doctors test the patient at the time of prescription or would information about everyone's genetic make-up be kept on a database that could be accessed by physicians or perhaps by pharmacists? Or would we have our own 'smart cards'?
In addition to developments in pharmacogenomics, there is increasing interest in analogous possibilities in nutrigenomics (Müller and Kersten, 2003). As society goes further down the path of grappling with the issues of the postgenome era, the relationship between genetics and diet is becoming increasingly central. The UK Department of Health White Paper, Our Inheritance, Our Future (2003) states that:

...the way external factors and genes interact to cause disease or protect us from disease will be better understood. This information will allow people with certain genetic profiles to avoid foods, chemicals or environmental factors, such as smoking, which are particularly risky for them (DoH, 2003.)

Here the issues of nutrigenomics arise: the application of genomics in nutrition research, enabling associations to be made between specific nutrients and genetic factors, e.g. the way in which foods or food ingredients influence gene expression; and the study of individual differences at the genetic level influencing response to diet.

\section{Ethics and the individual}

There have long been arguments that there is something special about genetics which makes the presumptions that have operated in medical ethics inappropriate. This idea about specialness is known as genetic exceptionalism. Genetic exceptionalism holds that there is a difference in kind between genetics and other areas of medicine, because, for example, genetic information is predictive, not specific to time, and shared between blood relatives. There is a weight of argument, however, against genetic exceptionalism that points to other areas of medicine that share, at least to some extent, some of these features: there are 
non-genetic tests that are predictive; a person's HIV status is relevant not only to him or herself.

Pharmacogenetics and nutrigenomics, however, raise anew the thesis of 'genetic exceptionalism'. What we might call pharmacogenetic exceptionalism suggests that pharmacogenetics will change the practice of medicine more than ever by producing 'personal pills' and challenging expectations of professional roles. Similar considerations apply with regard to nutrigenomics and the possibilities of individualised dietary advice. We have to consider suggestions of new paradigms in medicine and nutrition, following from the new scientific paradigms arising out of the Human Genome Project, and possibly new paradigms in ethics.

I think it is fair to say that in the context of clinical genetics and health service delivery, the prevailing ethical framework, what I call the 'standard view', has been individualistic, being based on the autonomy and choice of the individual.

- Individuals and couples undergoing genetic tests, particularly in the reproductive context, should have access to non-directive genetic counselling.

- Population screening should only be carried out where there is scope for action for the individuals who test positive.

- Individuals, on this model, have both a right to know and a right not to know genetic information about themselves, and

- should be given the opportunity for informed consent to donating a DNA sample.

It is also important, however, to have regard to constructions of individual identity in these contexts.

\section{Autonomy and identity}

We live in an era in which information, and individual choice, is, in general, prized. The argument for this can be supported from more than one kind of ethical perspectives, involving the notion of individual autonomy. Every ethical theory presupposes a particular understanding of the individual agent. From a utilitarian point of view, the individual agent is regarded as a utility maximizer - he or she will, if rational, act to promote their interests. Individual autonomy, on this perspective, consists in choosing what one sees as good, on the basis of what one wants. Each individual agent is helped in maximising his or her own utility by having the relevant information to take into account, e.g. about their future health risks, or predisposition to side effects from particular drugs, and this also arguably facilitates the utility of the larger group. It is in general in the best interests of society that individuals should make informed decisions about their own future good. Although in particular cases it may seem that the best consequences can be achieved by keeping people in ignorance, nevertheless we have seen several well publicised instances in the media of cases where a great deal of anger has been caused by people being denied information -in medical settings, in particular. So facilitating individual choice by making information available can be supported on the grounds that it tends to lead to the best overall consequences.

From another point of view, individual autonomy does not consist in pursuing one's interests as defined by one's desires or one's individual conception of the good. On the contrary, it consists in making a responsible choice, as a rational moral agent. It could be argued that there is a duty to be well-informed in order to fulfil one's duty to oneself and others. It is not that having the information will maximise one's utility: the question is whether a choice 
not to know a piece of genetic information is right. Consider the example of the option to know whether one had a genetic predisposition which made one much more likely to suffer from lung cancer if one smoked. Could a choice not to know this be supported - choosing not to know a piece of information that could be instrumental in preventing premature death? In the past few years, however, there have been more frequent arguments that there is a right not to know genetic information about ourselves (Chadwick et al., 1997). Although, as we have seen, there are considerations that favour making information available to individuals so that they can make informed choices about what is in their best interests, there is a difference between making information available and forcing it upon people if they do not want it. On the utilitarian version of autonomy, different utility maximisers might take different views, according to their own preferences and attitudes to risk. It is a commonplace that people differ in this respect. We make a distinction between those we call 'risk lovers' and those we call' risk averse'. Even if it is the case that there might be arguments for knowing genetic information that is potentially life-saving, however, the amount of genetic information that is covered by this criterion is a relatively small proportion.

Let us look at an example. There has been considerable debate over the question of whether there is a 'homosexuality gene', although it is now generally recognised that to speak in this way, of a 'gene for' a condition or characteristic, is very misleading. Genetic influences, where they exist, are likely to be very complex, not direct causal chains between one gene and one characteristic. That being said, let us suppose that it did become possible to have access to some information about genetic influences on one's sexual orientation. Here I want to turn to considerations of autonomy and identity. Today we recognise the important role that sexuality can play in an individual's identity. Establishing and protecting one's identity as an individual human is a wider if not a richer notion than the notion of moral agent. The right to preserve one's self-image has itself been advanced as an argument for a right not to know certain genetic information. Peter Widmer, for example, has argued that "I am not obliged to agree...to receive information ... which could lead me to modify my picture of myself in an undesirable manner" (Widmer, 1994). Although there may be problems arising from self-deception in some cases where an individual's selfimage is too far divorced from reality, we might think that there are reasons for understanding autonomy here in a different sense, in terms of making decisions about one's life as a whole, about what kind of person to be overall, rather than what to do in particular situations - for example, instead of thinking in terms of whether or not to take test $\mathrm{x}$ or not, the question would be: do I want to be the sort of person who takes every test available, or would I prefer to take things as they come? As the genetic 'revolution' advances, the latter choice may become reduced in some contexts. It may be the case that it will come to be regarded as negligent and contrary to medical ethics, for example, for doctors to prescribe medication without relevant genetic information, whether or not we want to know it ourselves. It is, then, not only the case that ethics can help us to think about what is acceptable in genetics, but advances in genetics can change our view about what is ethically acceptable.

Genes can also be associated with our conceptions of our own identity in a deeper sense. Whereas in the past it may have been the norm to think of one's identity in terms of one's soul, it is becoming more common to speak of one's identity as connected in some sense with the genes (Nelkin and Lindee, 1995). This to some 
extent explains the widespread revulsion towards reproductive cloning, and the objection expressed by many people to the deliberate creation of a being with an identical genome to another. It has to be said, however, that it can also explain some of the attraction of reproductive cloning to those who support it. People who have lost a loved one, for example, may think that it is possible to bring them back in some sense by creating a genetic 'replica' by cloning. This kind of thinking has been encouraged by stories that some scientists working on the Human Genome Project have claimed that an individual's identity could be encapsulated in a disk containing all their genetic information. Some have used 'reductionist' language suggesting that we can all, ultimately, be reduced to or explained by our DNA sequences, so that to know a person's genes is to know all there is to know about them. Others, however, suggest that this kind of thinking is a mistake. Human beings are much more than their genes: our environment and experiences play a part in creating who we are, so to try to recreate a lost loved one, even if reproductive cloning of humans were both practicable and permissible, would on this view result in disappointment.

Nevertheless, even if our identity as human beings cannot be completely reduced to our genes, it may well be true that our genes play a large part in influencing how we think about our selves, in more ways than the issue of how we take decisions about our future health. If it becomes possible to establish links between genetic factors and behavioural characteristics, as is envisaged by some, we may find ourselves as individuals given access to information about our tendency to be happy or sad, prone to take risks or cautious, and so on. It is not just how we think of our own future development as individuals, however, that is open to being affected by developments in genetics: there are also relational issues to consider. Knowledge about who our genetic relatives are, for example, has always been seen as important and it can be traumatic for those who either know nothing of their genetic parentage or find out that it is quite different from what they imagined, because we partly construct our identity in relation to others. We make choices not only as individuals, but also as members of a number of different groups. This will be very important in relation to biobanks.

Partly because of the need for research for the purposes of pharmacogenetics, we are now witnessing the setting up of large population databases, which will facilitate research of different kinds: association studies to establish links between genetic profiles and common disease; and association studies to establish response to drug toxicity, for example.

Let us consider a scenario in which a pharmaceutical company is undertaking a clinical trial to establish the safety and efficacy of a new product and, at the same time, to track the drug response against the genetic profiles of the participants. The participants are asked to give a separate consent to the traditional and the genetic aspects of the trial. What is different about the consent issues in the one case from the consent issues in the genetic aspects? Clinical trials in this area may have features that distinguish them from traditional clinical trials: first, it should be possible for clinical trials to become more targeted towards specific groups. For present purposes, however, the salient point is that they are likely to involve storage of DNA samples as responses to drugs are tracked over time, and this raises questions about the feasibility of informed consent. Another key change from the considerations outlined above concerns feedback: the focus of debate shifts from discussing an individual's choice or responsibility to know or not know genetic information, towards the issue of whether organisations 
involved in establishing databases have a duty to give feedback. In the course of the debates about genetic exceptionalism, generally concerns have been voiced about the possibility of genuine informed consent in genetics generally (Chadwick, 2001), for a number of reasons, but in the case of long term storage of DNA samples the issues become particularly complex because of the difficulty of making sense of 'consenting' to potential, but presently unforeseeable, uses of one's samples at some point in the future. The issue of predictability and storage is key here.

Beyond the issues for individuals, patients could be stratified according to genetic risk factors, as they are presently classified by other risk factors such as high blood pressure. In this connection the possible implications for particular population groups should be considered, in the light of possible differences between ethnic groups as regards, for example, slow or rapid rate of metabolising a drug. Given the complexity of these issues in relation to research databases for pharmacogenetic purposes, population wide biobanks, such as the proposed African-American one, for research and service delivery purposes are likely to be even more complicated, and bodies, such as the WHO, are recognising [in their draft report on genetic databases] that

The justification for a database is more likely to be grounded in communal value, and less on individual gain ... it leads to the question whether the individual can remain of paramount importance in this context

And again:

The achievement of optimal advances in the name of the collective good may require a reconsideration of the respective claims so as to achieve an appropriate balance between individual and collective interests, including those of ethnic minorities, from a multi-cultural perspective (WHO, 2001).

The question arises, then, as to what ethical resources we should be using in addressing the issues of genetic databases. The WHO appears to be suggesting a shift away from the paramountcy of the individual in favour of community interests.

The HUGO Ethics Committee in its Statement on Benefit-Sharing in 2000 (HUGO, 2000) addressed the issue of sharing the benefits of genetic research. On the one hand, some advocate that pharmaceutical companies who benefit from genomic research should make some return to the communities and families who have made increased revenues possible. On the other hand, those who oppose benefitsharing may suggest that people who contribute samples for research have not themselves done anything to make their sample valuable, that their samples become valuable by virtue of the work done by scientists. Also, a practical problem in sharing benefits is that many years could elapse between the original research and the development of a marketable drug. And efforts to distribute benefits may be seen as an attempt to buy people off. Recognising these difficulties, the HUGO Ethics Committee (2000) recommended that benefit-sharing should not be understood only in financial terms -'returns' can be of different kinds, e.g. starting with a 'thank you - but that companies should consider investing between 1 and 3\% of their net profits in health care infrastructure or other humanitarian endeavours.

While benefit-sharing is based on a principle of equity, according to the principle of solidarity, one could have a duty to facilitate research progress that could be crucial to the health of 
others, by, for example, making a 'gift' of one's sample. Turning to principles of solidarity and equity is a quite different approach from the individualistic one we considered earlier - the individual's right to decide whether to participate or refuse to participate in genetic research. It has been suggested that the post-genomic era might be the right time to rethink informed consent and the right to withdraw from or refuse to participate in research, provided that appropriate mechanisms regulating access to and use of the information are in place (Chadwick and Berg, 2001). As has been suggested above, there might, in fact, be risk to the individual qua member of a group, but this point strengthens the argument that the issues cannot be resolved by individual informed consent.

Partly because there are collective, rather than individual, interests to consider, public participation has moved higher up the agenda. There might be a number of objectives in public participation activities, consideration of which is beyond the scope of this discussion. I intend to consider, for present purposes, the objective of developing a communitarian consensus. Hub Zwart contrasts the liberal perspective - which has tended to emphasize not only personal autonomy but also a right to choose to have health care interventions- with the communitarian perspective which, according to Zwart, should aim at developing a consensus on the goals of medicine. From this point of view:

the moral agent should not be viewed in an atomistic way, but rather as situated in a moral community from which he derives his moral identity, his substantial moral convictions and his sense of direction. (Zwart, 1993, 53-4)

Zwart developed this argument in relation to priority setting in medicine, but it is also relevant to biobanks. Community consensus is not the same as a majority vote, which could be prejudicial to the interests of minority groups. It is dependent on a "normative, deontological framework defining the meaning of community interests” (ten Have, 1993, 45).

It might be objected, however, that in a pluralistic, post-modern society, a communitarian consensus of this kind is not possible; that the notion of community is not available (Poole, 1991), or that the effectiveness of the community-oriented criterion relies on its power to exclude - to silence some voices (van Willigenburg, 1993). Len Doyal has argued:

any local, community-based, small-scale form of need satisfaction can foster 'insider' conceptions of human need and inhibit the growth of generalisable notions based on a wider collective identity ... The dream of a community politics which could unite different groups ... cannot be realised in the absence of precisely such a cross-cultural and crossgroup source of identity as human need. (Doyal, 1991, 308-9).

It remains to be seen, therefore, whether democratic engagement can elucidate the required sources of collective identity to inform the debates about population based genomic research involving biobanks, a collective identity which goes beyond the majoritarian expression of individual preferences based on individual identity.

\section{Conclusion}

At the very least the situation we face in thinking about the appropriate ethical framework for genetic databases is one of increasing complexity. The thinking behind the doctrine of informed consent evolved in a very different situation from the one we face in the era of genomics. It is a context complicated by the 
global context of genetic research in addition to powerful commercial interests at stake. This suggests that it is not sufficient to take the approach of moving from an individual-centred ethic to a more community-centred approach; an approach of renegotiating the relationship between individual and community. This might be a necessary step, but we need also to be clear about what the interests at stake are, which may mean reconceiving the very terms 'individual' and 'community' in this context and the ways in which their interests are affected, identifying the sources of collective identity that are at stake.

It is not quite the picture that Milunsky (2001) envisages, then, of the individual taking increasing control. I spoke about the individual choosing as a utility maximizer, as responsible agent, and as choosing what sort of person they want to be. Even exercising control over my identity, however, has to be done with an eye to the context. I have to choose not what sort of person I want to be in isolation, but with an eye to my membership of different groups. What is the case is that every individual has to consider what the benefits are - what does it mean to call databases global public goods - in what sense are the global, what is meant by public, and what is meant by good are they really goods in which we all can share? The individualistic model that has prevailed so long has been a reaction to discredited eugenic policies, which arose from another type of 'public good' thinking which was inherently discriminatory.

In so far as there are new paradigms in ethical thinking in this context, this is the key focus - whether a new public good argument, that avoids these historic difficulties, can be made out.

\section{Acknowledgements}

The support of the Economic and Social Research Council (ESRC) is gratefully acknowledged. The work was part of the programme of the ESRC Research Centre for Economic and Social Aspects of Genomics.

\section{Bibliography}

Chadwick R, et al, eds. The Right to Know and the Right not to Know. Aldershot: Avebury; 1997.

Chadwick R. Informed consent in genetic research. In: Doyal L, Tobias J, eds. Informed Consent in Medical Research. London: BMJ Books; 2001: 203-10.

Chadwick R, Berg K. Solidarity and equity: new ethical frameworks for genetic databases. Nature Reviews Genetics 2001; 2: 318-21.

Department of Health. Our inheritance, our future: realising the potential of genetics in the NHS. London: Department of Health; 2003.

Doyal L, Gough I. A theory of human need. London: Macmillan; 1991.

ten Have H. Choosing core services in the Netherlands. Health Care Analysis 1993; 1: 43-7.

Human Genome Organization (HUGO) Ethics Committee. Statement on Benefit-Sharing. London: HUGO; 2000.

Milunsky A. Your Genetic Destiny: Know Your Genes, Secure Your Health, Save Your Life. Cambridge Mass: Perseus; 2001. 
Genomics, Public Health and Identity - R. Chadwick

Müller M, Kersten S. Nutrigenomics: goals and strategies. Nature Reviews Genetics 2003; 4 (4): 315-22.

Nelkin D, Lindee S.M. The DNA Mystique: the Gene as Cultural Icon. New York: W.H. Freeman; 1995.

Poole R. Morality and Modernity. London: Routledge; 1991.

Thorsteinsdôttir H, et al. Genoomics - a global public good? The Lancet 2003; 361 (9361): 891-2.

Van Willigenburg T. Communitarian illusions, or why the Dutch proposal for setting priorities in health care must fail. Health Care Analysis 1993; 1: 49-52.

Widmer P. Human rights issues in research on medical genetics. In: Ethics and Human Genetics. Strasbourg: Council of Europe; 1994: 175-188.

World Health Organization. Genetic Databases: Assessing the Benefits and the Impact on Human \& Patient Rights. Report for Consultation 2001. 